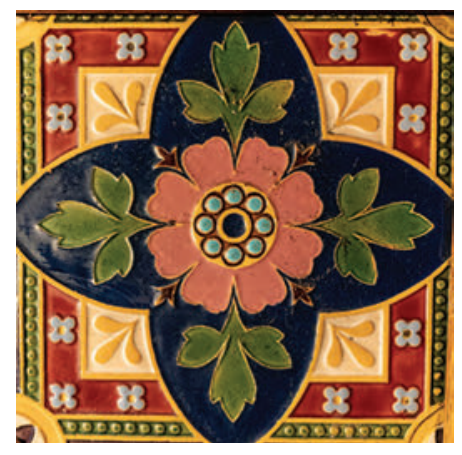

\title{
A Tradition of Excellence in 150 Notable Books
}

Tn celebration of the I5oth anniversary of our founding, 1 Cornell University Press presents 150 of our most notable books. These are bestsellers and award winners, books written by distinguished authors and that have made particularly important contributions to their fields-as well as books that are beloved by the staff or are important records of Cornell history. Drawing from close to 7,000 publications, our selections span the broad range of humanities and science fields in which we have published and reflect just a fraction of the important works and authors we have been proud to bring to the world.

I869 Cornell University Register

I888 John Henry Comstock, An Introduction to Entomology

I893 John Henry Comstock and Simon Henry Gage, eds., Wilder Quarter-Century Book: A Collection of Original Papers Dedicated to Professor Burt Green Wilder

I894 Simon Gage, The Microscope

I9II Anna Botsford Comstock, Handbook of Nature-Study for Teachers and Parents

I922 John Henry Comstock and William Gould Vinal, Field and Camp Notebook 
I926 Anna Botsford Comstock, Ways of the Six-Footed

I933 Anna Allen Wright and Albert Hazen Wright, Handbook of Frogs and Toads: The Frogs and Toads of the United States and Canada

I935 H. H. Dukes, Physiology of Domestic Animals

I939 Linus Pauling, Nature of the Chemical Bond and the Structure of Molecules and Crystals: An Introduction to Modern Structural Chemistry

I939 Andrew Dickson White, Selected Chapters from the Autobiography of Andrew D. White

I94I Edmund Ezra Day, Defense of Freedom: Four Addresses on the Present Crisis in American Democracy

I942 Albert R. Brand Bird Song Foundation, Laboratory of Ornithology, Cornell University, American Bird Songs (sound recording)

I942 Hieronymous Fabricius, Embryological Treatises of Hieronymous Fabricius of Aquapendente, with an introduction, translation, and commentary by Howard B. Adelmann (2 vols.)

I942 Carl Stephenson, Mediaeval Feudalism

I943 Carl L. Becker, Cornell University: Founders and the Founding

I945 Carl L. Becker, Safeguarding Civil Liberty Today: The Edward L. Bernays Lectures of 1944 given at Cornell University

I946 Walter Conrad Leopold Muenscher, Keys to Woody Plants

I947 Lane Cooper, Aristotle on the Art of Poetry

I949 Ruby Green Smith, The People's Colleges: A History of the New York State Extension Service in Cornell University and the State, 1876-1948
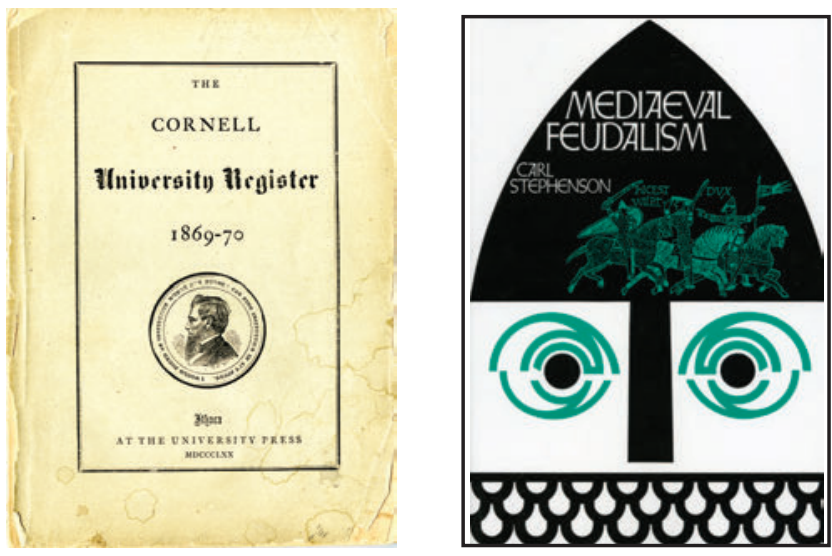

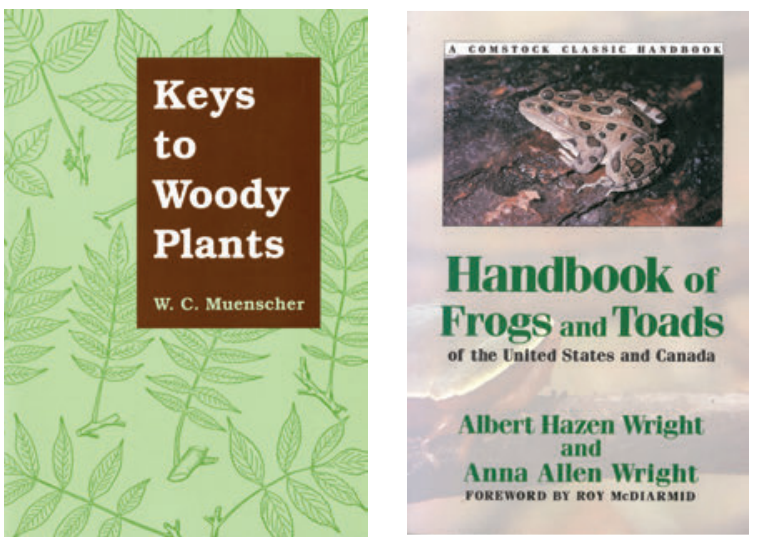

I949 Moses Coit Tyler, A History of American Literature, 1607-1765

I950 Walter Gellhorn, Security, Loyalty, and Science

I950 Karl von Frisch, Bees: Their Vision, Chemical Senses, and Language

I952 George Lenczowski, The Middle East in World Affairs

I954 Max Black, Problems of Analysis: Philosophical Essays

I954 Milton R. Konvitz, ed., Bill of Rights Reader: Leading Constitutional Cases

I954 Harry M. Orlinsky, Ancient Israel

I955 E. Harris Harbison, The Age of Reformation

I955 Ralph Vaughan Williams, The Making of Music

I956 R. E. Snodgrass, Anatomy of the Honey Bee

I957 G. E. M. Anscombe, Intention

I957 Charles Homer Haskins, The Rise of Universities

I958 Cadwallader Colden, The History of the Five Indian Nations

Depending on the Province of New-York in America

I960 Clinton Rossiter, Parties and Politics in America

I961 Henry Guerlac, Lavoisier: The Crucial Year: The Background and Origin of His First Experiments on Combustion in 1772

I962 Morris Bishop, A History of Cornell

I962 Heinz Politzer, Franz Kafka: Parable and Paradox

I963 Walter Lafeber, The New Empire: An Interpretation of American Expansion, $1860-1898$ 
I964 Angus Fletcher, Allegory: The Theory of a Symbolic Mode

I965 A. R. Ammons, Tape for the Turn of the Year

I966 David Brion Davis, The Problem of Slavery in Western Culture

I967 Claire Holt, Art in Indonesia: Continuities and Change

I967 Alvin Plantinga, God and Other Minds: A Study of the Rational Justification of Belief in God

I967 Victor Turner, The Forest of Symbols: Aspects of Ndembu Ritual

I968 Giambattista Vico, The New Science of Giambattista Vico: Unabridged Translation of the Third Edition (1744), translated by Thomas Goddard Bergin and Max Harold Fisch

I969 Donald Kagan, A New History of the Peloponnesian War (4 vols.)

I970 Victor Shklovsky, A Sentimental Journey: Memoirs, 1917-1922

I97I Joseph Hayyim Brenner, Breakdown and Bereavement: A Novel, translated from the Hebrew by Hillel Halkin

I97I George Gibian, trans. and ed., Russia's Literature of the Absurd: A Literary Discovery. Selected Works of Daniil Kharms and Alexander Vvedensky

I97I Georg Henrik von Wright, Explanation and Understanding

I97I Mack Walker, German Home Towns: Community, State, and General Estate, ${ }_{1648-1871}$

I972 Jeffrey Burton Russell, Witchcraft in the Middle Ages

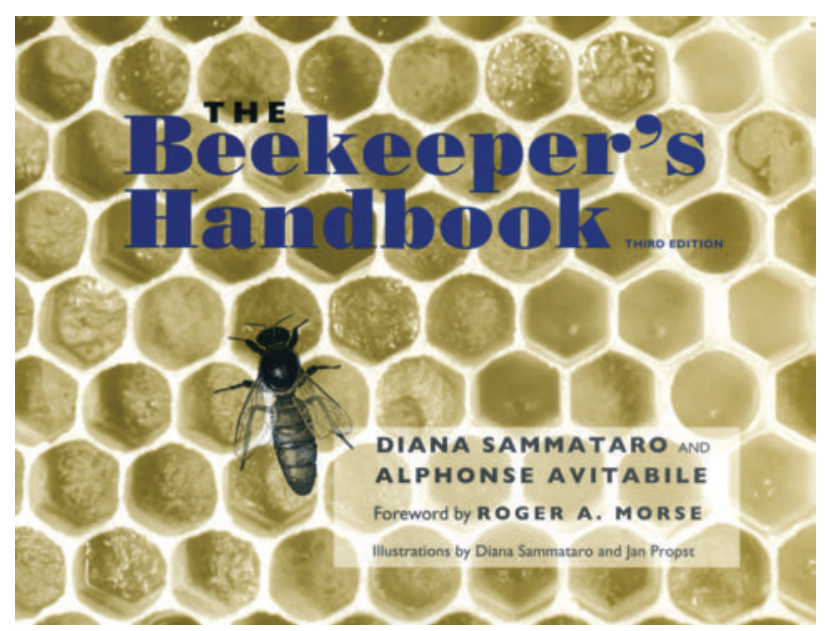


I972 Carl Sagan and Thornton Page, eds., UFO's: A Scientific Debate

I973 Diana Sammataro and Alphonse Avitabile, The Beekeeper's Handbook

I974 Barbara G. Myerhof, Peyote Hunt: The Sacred Journey of the Huichol Indians

I975-2007 William Wordsworth, The Cornell Wordsworth (2I vols.)

I977 Marquis de Lafayette, Lafayette in the Age of the American Revolution: Selected Letters and Papers, 1776-1790, edited by Stanley J. Idzerda, Roger E. Smith, Linda J. Pike, Mary Ann Quinn, and Robert R. Crout (5 vols.)

I977 Norman Malcolm, Memory and Mind

I978 Seymour Chatman, Story and Discourse: Narrative Structure in Fiction and Film

I978 William Murphy, Prodigal Father: The Life of John Butler Yeats (1839-1922)

I980 Nina Baym, Woman's Fiction: A Guide to Novels by and about Women in America, $1820-1870$

I980 William R. Biers, The Archaeology of Greece: An Introduction

I980 Harold Bloom, Wallace Stevens: The Poems of Our Climate

I980 Michael Kammen, ed., The Past before Us: Contemporary Historical Writing in the United States

The

Archaeology of Greece

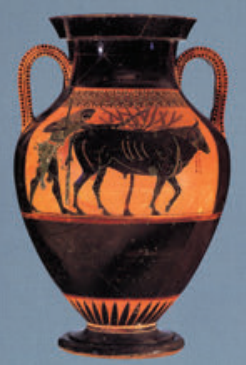

WILLIAM R. BIERS

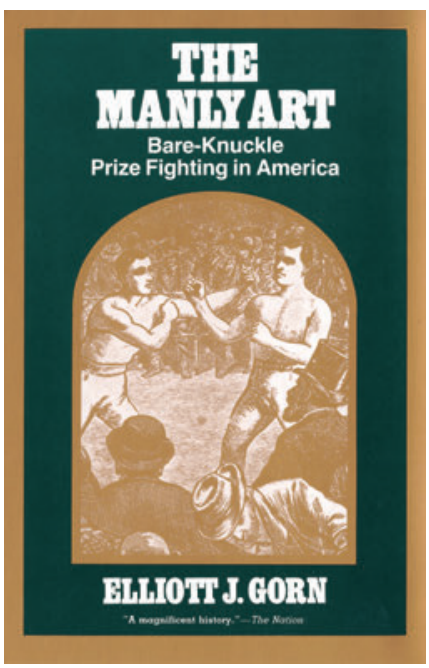


I980 Merritt Roe Smith, Harpers Ferry Armory and the New Technology: The Challenge of Change

I98I Whitney R. Cross, Burned-over District: The Social and Intellectual History of Enthusiastic Religion in Western New York, 1800-1850

I98I Fredric Jameson, The Political Unconscious: Narrative as a Socially Symbolic Act

I982-20I3 William Butler Yeats, The Cornell Yeats (33 vols.)

I982 Jonathan Culler, On Deconstruction: Theory and Criticism after Structuralism

I982 Geoffrey E. Maurice Ste. Croix, The Class Struggle in the Ancient Greek World: From the Archaic Age to the Arab Conquests

I983 Dominick LaCapra, Rethinking Intellectual History: Texts, Contexts, Language

I984 Ivo Banac, The National Question in Yugoslavia: Origins, History, Politics

I984 Plato and Aristophanes, Four Texts on Socrates: Plato's "Euthyphro," "Apology," and "Crito" and Aristophanes' "Clouds," translated with notes by Thomas G. West and Grace Starry West, introduction by Thomas G. West

I985 Luce Irigaray, Speculum of the Other Woman
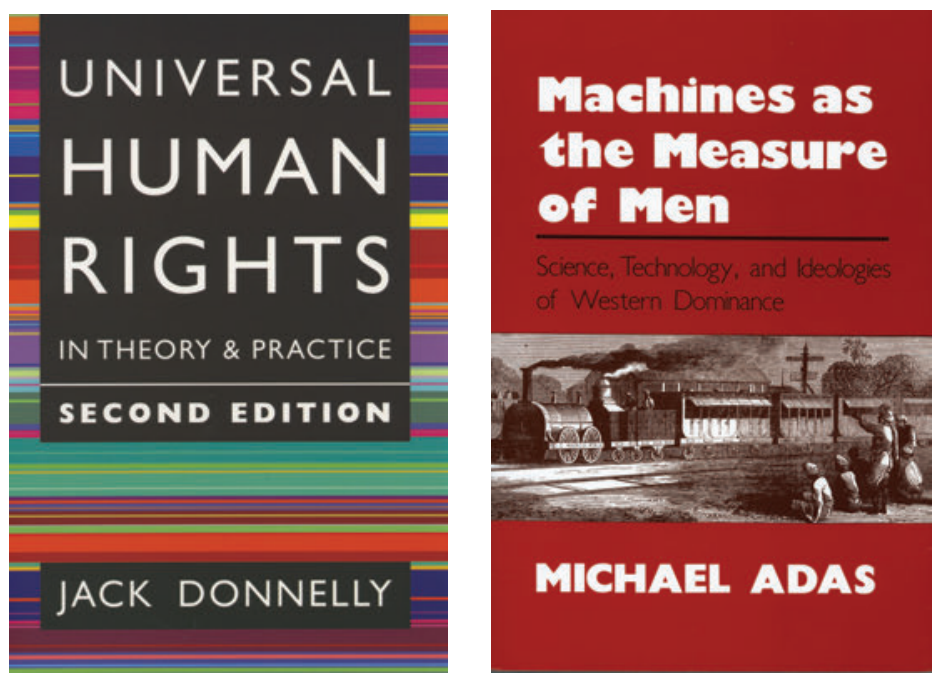
I985 Peter Katzenstein, Small States in World Markets: Industrial Policy in Europe

I985 Nancy B. Reich, Clara Schumann: The Artist and the Woman

I986 Jack Flam, Matisse: The Man and His Art, 1869-1918

I986 Elliot J. Gorn, The Manly Art: Bare-Knuckle Prize Fighting in America

I986 Sandra Harding, The Science Question in Feminism

I987 Charles Darwin, Charles Darwin's Notebooks 1836-1844: Geology, Transmutation of Species, Metaphysical Enquiries, transcribed and edited by Paul H. Barrett, Peter J. Gautrey, Sandra Herbert, David Kohn, and Sydney Smith

I987 Wayne A. Sinclair, Howard H. Lyon, and Warren T. Johnson, Diseases of Trees and Shrubs

I988 P. V. Glob, The Bog People: Iron-Age Man Preserved

I989 Jack Donnelly, Universal Human Rights in Theory and Practice

I989 Robert Jervis, The Meaning of Nuclear Revolution: Statecraft and the Prospect of Armageddon

I989 Barbara Kingsolver, Holding the Line: Women in the Great Arizona Mine Strike of 1983

I989 Alexander F. Skutch, Life of the Tanager, illustrated by Dana Gardner

I989 Gary Stiles and Alexander F. Skutch, A Guide to the Birds of Costa Rica, illustrated by Dana Gardner

I990 Michael Adas, Machines as the Measure of Men: Science, Technology, and Ideologies of Western Dominance

I990 Benedict Anderson, Language and Power: Exploring Political Cultures in Indonesia

I990 Robert V. Bruce, Bell: Alexander Graham Bell and the Conquest of Solitude

I990 Peter Kivy, Music Alone: Philosophical Reflections on the Purely Musical Experience

1990 Gregory Nagy, Greek Mythology and Poetics

I99I William P. Alston, Perceiving God: The Epistemology of Religious Experience

I99I Peter Uwe Hohendahl, Reappraisals: Shifting Alignments in Postwar Critical Theory 
I99I Joseph M. Levine, Battle of the Books: History and Literature in the Augustan Age

I991 Tom Lutz, American Nervousness, 1903: An Anecdotal History

I99I Robert B. Westbrook, John Dewey and American Democracy

I992 Donald Harman Akenson, God's Peoples: Covenant and Land in South Africa, Israel, and Ulster

I992 Laura Engelstein, The Keys to Happiness: Sex and the Search for Modernity in fin-de-siècle Russia

I992 Roy Rosenzweig and Elizabeth Blackmar, The Park and the People: A History of Central Park

I993 Angela Miller, The Empire of the Eye: Landscape Representation and American Cultural Politics, 1825-1875

I993 Jesper Svenbro, Phrasikleia: An Anthropology of Reading in Ancient Greece

I994 William Cobbett, Peter Porcupine in America: Pamphlets on Republicanism and Revolution, edited and with an introduction by David A. Wilson

I994 Richard J. Samuels, "Rich Nation, Strong Army": National Security and the Technological Transformation of Japan

I995 Albert Bates Lord, The Singer Resumes the Tale, edited by Mary Louise Lord

I996 Mary Beth Norton, Liberty's Daughters: The Revolutionary Experience of American Women, 1750-1800

I997 Margaret E. Keck and Kathryn Sikkink, Activists beyond Borders: Advocacy Networks in International Politics

I997 Charles W. Mills, The Racial Contract

I997 Richard H. Uva, Joseph C. Neal, and Joseph M. DiTomaso, Weeds of the Northeast

I998 Alan Derickson, Black Lung: Anatomy of a Public Health Disaster

I999 Donald Alexander Downs, Cornell '69: Liberalism and the Crisis of the American University

I999 Alma Mahler-Werfel, Diaries, 1898-1902, selected and translated by Anthony Beaumont

2000 Karl Reichl, Singing the Past: Turkic and Medieval Heroic Poetry 

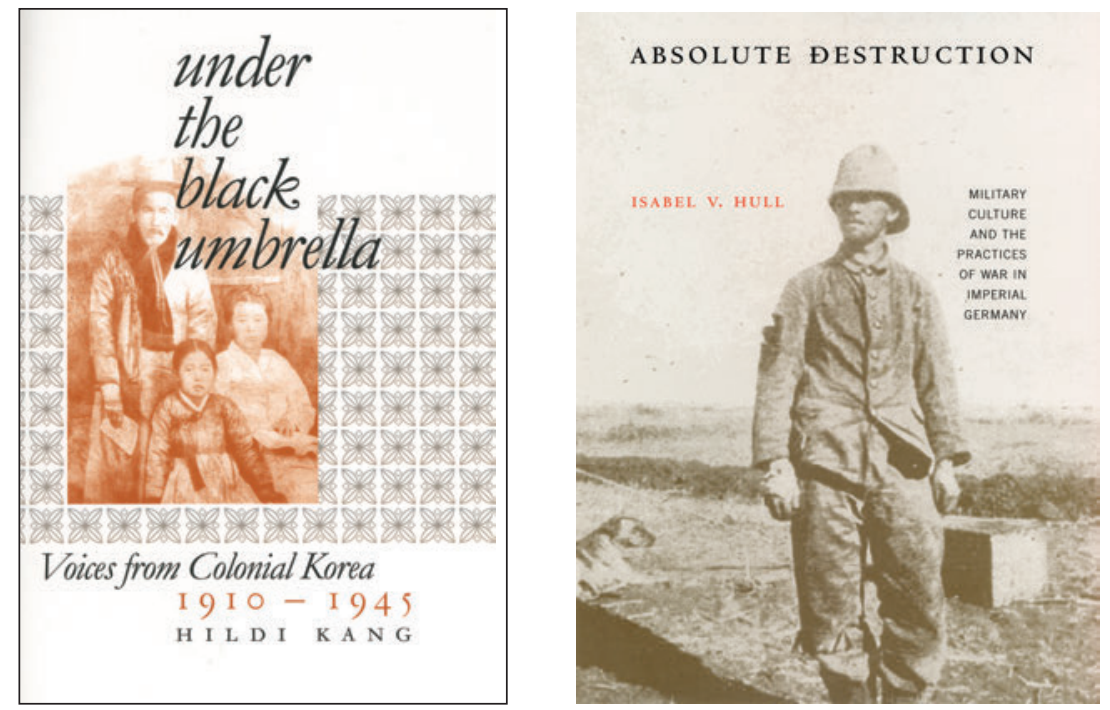

2000 Michael Zweig, The Working Class Majority: America’s Best Kept Secret

200I William Hansen, Ariadne's Thread: A Guide to International Stories in Classical Literature

200I Hildi Kang, Under the Black Umbrella: Voices from Colonial Korea, 1910-1945

200I Stuart J. Kaufman, Modern Hatreds: The Symbolic Politics of Ethnic War

200I Terry Martin, The Affirmative Action Empire: Nations and

Nationalism in the Soviet Union, 1923-1939

200I Leon Stein, The Triangle Fire

200I Heather Ann Thompson, Whose Detroit? Politics, Labor, and Race in a Modern American City

2002 Michael Barnett, Eyewitness to a Genocide: The United Nations and Rwanda

2002 Elaine Forman Crane, Killed Strangely: The Death of Rebecca Cornell

2002 Suzanne Gordon and Bernice Buresh, From Silence to Voice: What Nurses Know and Must Communicate to the Public

2002 Fiona Terry, Condemned to Repeat: The Paradox of Humanitarian Action 
2003 Martha Finnemore, The Purpose of Intervention: Changing Beliefs about the Use of Force

2003 P. W. Singer, Corporate Warriors: The Rise of the Privatized Military Industry

2003 Dana Beth Weinberg, Code Green: Money-Driven Hospitals and the Dismantling of Nursing

2004 Francis Fukuyama, State-Building: Governance and World Order in the 21st Century

2005 Jan Assmann, Death and Salvation in Ancient Egypt, translated by David Lorton

2005 Francine Hirsch, Empire of Nations: Ethnographic Knowledge and the Making of the Soviet Union

2005 Isabel V. Hull, Absolute Destruction: Military Culture and the Practices of War in Imperial Germany

2005 Rebekah Nathan, My Freshman Year: What a Professor Learned by Becoming a Student

2005 Gérard Prunier, Darfur: The Ambiguous Genocide

2006 Sergey Prokofiev, Diaries 1907-1914: Prodigious Youth; Diaries 19151923: Behind the Mask; Diaries 1924-1933: Prodigal Son, translated by Anthony Phillips (3 vols.)
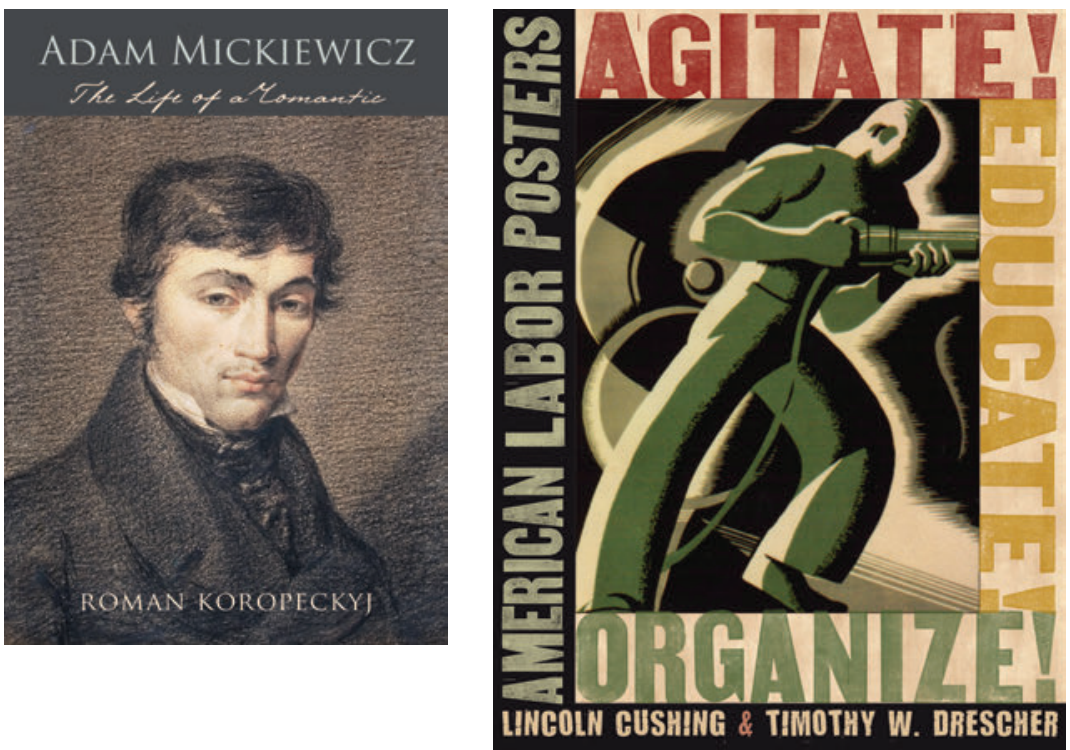
2007 Raymond Clemens and Timothy Graham, Introduction to Manuscript Studies

2008 Liberty Hyde Bailey, Liberty Hyde Bailey: Essential Agrarian and Environmental Writings, edited by Zachary Michael Jack

2008 Roman Koropeckyj, Adam Mickiewicz: The Life of a Romantic

2009 Lincoln Cushing and Timothy W. Drescher, Agitate! Educate! Organize! American Labor Posters

20II Elizabeth Eva Leach, Guillaume de Machaut: Secretary, Poet, Musician

20II Nancy Leys Stepan, Eradication: Ridding the World of Diseases Forever?

20I2 Frank H. T. Rhodes, Earth: A Tenant's Manual

2012 Augustine Thompson, O.P., Francis of Assisi: A New Biography

2012 Tom Wilber, Under the Surface: Fracking, Fortunes, and the Fate of the Marcellus Shale

2013 Saru Jayaraman, Behind the Kitchen Door

2013 Mark Thompson, Birth Certificate: The Story of Danilo Kiš

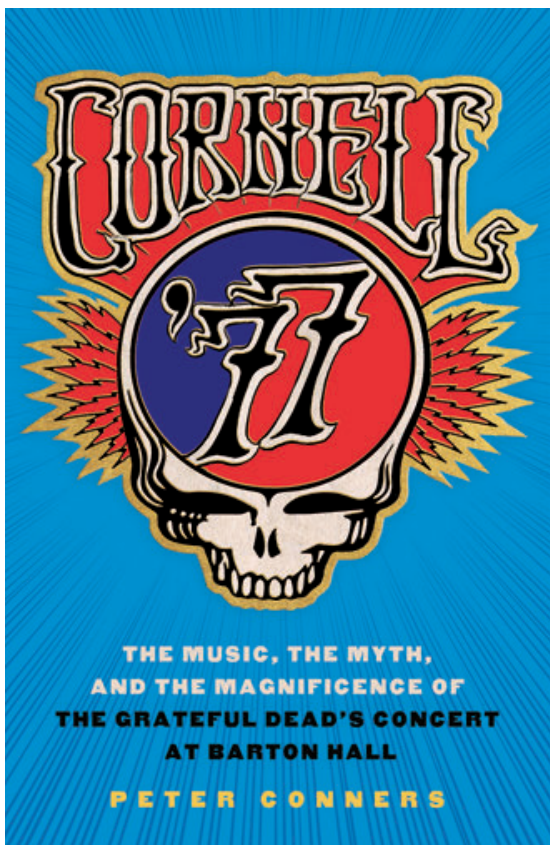


2013 Charity Vogel, The Angola Horror: The 1867 Train Wreck that Shocked the Nation and Transformed American Railroads

2015 Scott Straus, Making and Unmaking Nations: War, Leadership, and Genocide in Modern Africa

2016 Max Bergholz, Violence as a Generative Force: Identity, Nationalism, and Memory in a Balkan Community

2016 Marisa Scheinfeld, Borscht Belt: Revisiting the Remains of America's Jewish Vacationland

2017 Peter Conners, Cornell '77: The Music, the Myth, and the Magnificence of the Grateful Dead's Concert at Barton Hall 